\title{
LACTIC ACID PRODUCTION DURING REST AND AFTER EXERCISE IN SUBJECTS WITH VARIOUS TYPES OF HEART DISEASE WITH SPECIAL REFERENCE TO CONGENITAL HEART DISEASE ${ }^{1}$
}

\author{
By PHILLIP HALLOCK \\ (From the Division of Internal Medicine, University of Minnesota Hospitals, Minneapolis)
}

(Received for publication December 19, 1938)

The defects found in congenital heart disease are frequently of such character as to disturb the normal pathways of circulation through the heart. The common types of congenital lesions responsible for diverting the normal course of blood are interventricular septal defects with or without pulmonary stenosis, auricular septal defects, and patent ductus arteriosus. In these anomalies the hemodynamic relationship between the right and left side of the heart becomes so altered as to lead to a mechanical interference with the proper oxygenation of the blood. When this obtains, quantities of blood pass unaerated (venous-arterial shunt) from the right to the left side of the heart giving rise to varying degrees of oxygen unsaturation, cyanosis, and anoxemia. On the other hand, the course of the blood stream may be shunted from the left to the right side of the heart (arterial-venous shunt), thereby permitting oxygenated blood to pass back into the lesser circulation. Under the latter conditions there may be neither anoxemia nor cyanosis.

In this study we have sought to obtain data regarding the presence or absence of anoxemia and factors influencing its development. Information of this kind is of course important in congenital heart afflictions because prognoses, particularly of the potentially more serious defects, depend in general on the degree of anoxemia and the extent of the increase of the work of the heart. The degree of cyanosis is a valuable guide, but is not an accurate measure of anoxemia. If polycythemia is present, there may be a sufficient quantity of oxygen for the tissues and, in addition, enough reduced hemoglobin to cause cyanosis. Conversely, anoxemia may be present without visible cyanosis. We have attempted here to investigate this problem by studying the variations

1 This study was carried out in the Medical Unit of Wilhelmina Hospital, University of Amsterdam, and the Cardiac Department of London Hospital, London. in blood lactic acid levels at rest and following slight exercise. The amount of lactic acid in the blood can be utilized as a measure of anoxemia since it is recognized that a reduction in the oxygen supply to the tissues can, by inhibiting the oxidative recovery process, prevent the combustion of lactic acid and its conversion to glucose, thus giving rise to the accumulation of this substance in the tissues and blood stream $(1,2)$.

\section{METHOD}

The investigation was carried out in the morning with the subjects in the fasting state. The patients rested at least thirty minutes before being placed in the chairergometer, and a sample of blood was drawn from the anterior cubital vein. With the exception of a few who were too ill, all subjects were subjected to a mild exercise test. The exercise on the chair-ergometer is simple and easily executed after the subject has been given a few simple instructions. Briefly, the apparatus consists of a comfortable chair projecting out from which is a double set of small tracks. The feet are fastened to two runners which in turn fit on the tracks. In the act of extension of the legs a set of weights, connected to the heels of the runners by a combination of bicycle chains, are raised a given distance. The work performed is calculated in terms of kilogrammeters. An average of about 1500 $\mathrm{kgm}$. $\mathrm{m}$. of work was done in ten minutes. We have considered this amount of physical work as equivalent to mild exercise. Several patients, however, were unable to carry out this amount of exercise because of fatigue and dyspnea. After exercise the subject remained sitting quietly in the chair. Seven minutes after the cessation of exercise a second sample of blood was removed from the anterior cubital vein. Lactic acid reaches a maximum concentration in the anterior cubital vein seven minutes after the termination of work on the chair-ergometer (3).

The samples of blood were then analyzed for lactic acid in duplicate or triplicate by the method of Freidemann, Cotonio, and Shaffer (4). The error involved in the method is no greater than $1 \mathrm{mgm}$. per cent.

\section{MATERIAL}

Thirty-nine persons were studied. In several instances the individual experiments were re- 
peated. Of the total number tested eighteen were patients with congenital heart disease (Tables II and III) with clinical or radioscopic evidence of either intra or extra cardiac communications between the venous and arterial circulation. In this group eight were diagnosed as having interventricular septal defects; seven cases showed the classical findings of patent ductus arteriosus; two cases with permanent cyanosis were diagnosed as tetralogy of Fallot; and one case possessed either an interventricular septal defect or a patent auricular septal defect. The diagnosis in each of the eighteen cases of congenital heart disease was based on the auscultatory findings, radioscopic appearance of the heart, and electrocardiographic evidence. In two cases it was necessary to rely solely on the auscultatory findings because of the absence of enlargement of one or more chambers of the heart and the absence of enlargement of the pulmonary artery. In these two cases, however, the auscultatory findings were quite conclusive in respect to the location and character of the murmur and of the accompanying localized thrill.

Ten of the subjects studied had normal cardiovascular systems and their ages ranged from ten to fifty-nine years. There were six cases of acquired valvular defects, two of which were associated with auricular fibrillation. Of the remaining five cases there were two of coronary thrombosis, two of hypertension associated with coronary disease, and one of ventricular tachycardia.

\section{RESULTS}

The concentration of lactic acid in venous blood of the normal human at rest with the Freidemann, Cotonio, and Shaffer method (4) varies from 10 to $20 \mathrm{mgm}$. per $100 \mathrm{cc}$. of blood (5). Table I shows the lactic acid values obtained from ten normal subjects at rest and after the above described mild exercise. After these same individuals were submitted to our exercise test the concentration of venous blood lactate never exceeded $21 \mathrm{mgm}$. per $100 \mathrm{cc}$. The average concentration of lactic acid at the resting level was 13.8 mgm. per $100 \mathrm{cc}$. while after mild exercise it was $16.3 \mathrm{mgm}$., an average increase of slightly more than $2 \mathrm{mgm}$. per $100 \mathrm{cc}$. No patient showed nor complained of fatigue or dyspnea after the exer-
TABLE I

Lactic acid content of venous blood during rest and after exercise in normal subjects

\begin{tabular}{|c|c|c|c|c|c|}
\hline \multirow{2}{*}{ Case } & \multirow{2}{*}{ Age } & \multirow{2}{*}{ Sex } & \multirow{2}{*}{$\begin{array}{l}\text { Amount } \\
\text { of work } \\
\text { performed }\end{array}$} & \multicolumn{2}{|c|}{ Lactic acid } \\
\hline & & & & Before & After \\
\hline \multirow{3}{*}{$\begin{array}{r}1 \\
2 \\
3 \\
4 \\
5 \\
6 \\
7 \\
8 \\
9 \\
10 \\
11\end{array}$} & \multirow{3}{*}{$\begin{array}{c}\text { years } \\
22 \\
23 \\
11 \\
19 \\
13 \\
24 \\
13 \\
59 \\
10 \\
24 \\
35\end{array}$} & \multirow{3}{*}{$\begin{array}{l}\mathbf{F} \\
\mathbf{M} \\
\mathbf{F} \\
\mathbf{F} \\
\mathbf{M} \\
\mathbf{M} \\
\mathbf{F} \\
\mathbf{M} \\
\mathbf{F} \\
\mathbf{M} \\
\mathbf{M}\end{array}$} & kgm. m. & $\begin{array}{l}\text { mgm. per } \\
100 \mathrm{cc} \text {. }\end{array}$ & $\begin{array}{c}\text { mgm. per } \\
100 \text { cc. }\end{array}$ \\
\hline & & & $\begin{array}{l}1,260 \\
1,440 \\
1,050 \\
1,287 \\
1,350 \\
1,920 \\
1,092 \\
2,000 \\
350 \\
1,700 \\
1,500\end{array}$ & $\begin{array}{l}12.8 \\
10.3 \\
13.6 \\
11.4 \\
15.0 \\
15.8 \\
12.6 \\
15.3 \\
12.0 \\
15.4 \\
17.7\end{array}$ & $\begin{array}{l}15.0 \\
12.9 \\
16.6 \\
13.7 \\
17.0 \\
16.4 \\
16.8 \\
20.5 \\
17.2 \\
15.8 \\
17.8\end{array}$ \\
\hline & & & Average & 13.8 & 16.3 \\
\hline
\end{tabular}

cise and all stated they could carry on without any difficulty.

The resting lactic acid levels and those following mild exercise for the cases with venous arterial shunts are tabulated in Table II. These patients are classified under the cyanotic group because of permanent cyanosis or its development after exercise (transient type). The changes in the concentration of the lactic acid following exercise are obviously marked, with the exception of Case 16. In every other instance there is more than a 65 per cent increase. Two separate experiments were carried out on Case 16 and the results were substantially in agreement, showing a 9 per cent increase from the resting value after the exercise test.

A fairly definite relationship exists between the lactic acid concentration and dyspnea, the patients with the highest lactic acid levels showed the greatest amount of dyspnea after exercise. (See Table II.)

Twelve cases comprise the acyanotic group (Table III). None showed visible cyanosis before or after mild exercise. The highest lactic acid concentration after exercise was found in Case 21. In this group the height of concentration of lactic acid after exercise was again related to the degree of dyspnea. In those cases in which the lactic acid response was within the normal range, dyspnea was neither observed nor noted by the patient. This table further indicates that the blood lactic acid values may rise well above the 
TABLE II

Cyanotic group. Lactic acid levels of venous blood before and after standard exercise in those cases of congenital heart disease associated with venous-arterial shunts

\begin{tabular}{|c|c|c|c|c|c|c|c|c|c|}
\hline \multirow{2}{*}{ Case } & \multirow{2}{*}{ Age } & \multirow{2}{*}{ Sex } & \multirow{2}{*}{ Diagnosis } & \multirow{2}{*}{$\begin{array}{l}\text { Work } \\
\text { performed }\end{array}$} & \multicolumn{2}{|c|}{ Lactic acid } & \multirow{2}{*}{$\begin{array}{l}\text { Hemo- } \\
\text { globin* }\end{array}$} & \multirow{2}{*}{$\begin{array}{l}\text { Red } \\
\text { blood } \\
\text { cells }\end{array}$} & \multirow{2}{*}{ Remarks } \\
\hline & & & & & Before & After & & & \\
\hline 11 & $\begin{array}{c}\text { years } \\
63\end{array}$ & $\mathbf{M}$ & $\begin{array}{l}\text { Interventricular sep- } \\
\text { tal defect }\end{array}$ & $\begin{array}{c}\mathrm{kgm} . \mathrm{m} . \\
1200\end{array}$ & $\begin{array}{l}\text { mgm. } \\
\text { per cent } \\
18.44\end{array}$ & $\begin{array}{l}\text { mgm. } \\
\text { per cent } \\
43.25\end{array}$ & $\begin{array}{c}\text { per cent } \\
121\end{array}$ & $\begin{array}{c}\text { millions } \\
7.5\end{array}$ & $\begin{array}{l}\text { Cyanotic; became dyspneic } \\
\text { after this exercise and } \\
\text { cyanosis more intense }\end{array}$ \\
\hline 12 & 19 & $\mathbf{M}$ & Tetralogy of Fallot & 540 & 17.98 & 40.94 & 106 & 11.0 & $\begin{array}{l}\text { Continuous cyanosis since } \\
\text { birth; became extremely } \\
\text { dyspneic and blue after } \\
\text { this amount of exercise }\end{array}$ \\
\hline 13 & 17 & $\mathbf{F}$ & Tetralogy of Fallot & 1350 & 16.03 & 28.44 & 132 & 7.5 & $\begin{array}{l}\text { Cyanotic all her life. Cy- } \\
\text { anosis increased after } \\
\text { work. Developed slight } \\
\text { dyspnea after exercise }\end{array}$ \\
\hline 14 & 23 & $\mathbf{F}$ & Patent ductus & 875 & 13.20 & 28.68 & 90 & 5.0 & $\begin{array}{l}\text { Slight degree of cyanosis. } \\
\text { Cyanosis did not increase } \\
\text { after work. Slightly dysp- } \\
\text { neic and fatigued after } \\
\text { exercise }\end{array}$ \\
\hline 14 & 23 & $\mathbf{F}$ & Patent ductus & 984 & 13.30 & 27.54 & & & As above \\
\hline 15 & 21 & $\mathbf{F}$ & $\begin{array}{l}\text { Interventricular sep- } \\
\text { tal defect associated } \\
\text { with patent ductus } \\
\text { arteriosus }\end{array}$ & 1720 & 20.88 & 47.10 & 82 & 5.0 & $\begin{array}{l}\text { No cyanosis but became } \\
\text { cyanotic after exercise. } \\
\text { Complained of fatigue. } \\
\text { Moderate degree of dysp- } \\
\text { nea }\end{array}$ \\
\hline 15 & 21 & $F$ & $\begin{array}{l}\text { Interventricular sep- } \\
\text { tal defect associated } \\
\text { with patent ductus } \\
\text { arteriosus }\end{array}$ & 1475 & 18.48 & 29.56 & & & As above \\
\hline 16 & 25 & $\mathbf{M}$ & $\begin{array}{l}\text { Interventricular sep- } \\
\text { tal defect with pat- } \\
\text { ent ductus }\end{array}$ & 1512 & 20.78 & 22.01 & 130 & 7.0 & $\begin{array}{l}\text { Slight to moderate cya- } \\
\text { nosis. Not fatigued nor } \\
\text { dyspneic after exercise. } \\
\text { Cyanosis more marked } \\
\text { after exercise }\end{array}$ \\
\hline \multirow[t]{2}{*}{16} & 25 & $\mathbf{M}$ & $\begin{array}{l}\text { Interventricular sep- } \\
\text { tal defect with pat- } \\
\text { ent ductus }\end{array}$ & 1800 & 18.85 & 22.57 & & & As above \\
\hline & & & & Average & 17.58 & 32.00 & & & \\
\hline
\end{tabular}

* 17 grams of hemoglobin per $100 \mathrm{cc}$. of blood is equivalent to 100 per cent hemoglobin.

upper range of normal (Cases 17, 18, 21, 22, 23) without the development of cyanosis. Thus, the abnormal rise of lactic acid is not necessarily associated with cyanosis.

In Table IV are shown the lactic acid values in chronic valvular defects with and without auricular fibrillation. In the two cases of mitral stenosis associated with auricular fibrillation (Cases 31 and 32) there was a definitely abnormal rise in the lactic acid values following exercise. In Case 31 a slight amount of cyanosis developed but in Case 32 this phenomenon was absent, yet both developed dyspnea after the exercise test. In Case 29, likewise, an abnormal lactic acid rise was observed and even in the absence of auricular fibrillation, dyspnea developed after $1500 \mathrm{kgm}$. m. of work. In the remaining cases no abnormal response was obtained. In Case 35 a slightly elevated resting lactic acid value was obtained.

Several interesting findings are brought out in 


\section{TABLE III}

Acyanotic group. Lactic acid levels of venous blood before and after standard excercise in those cases of congenital heart disease associated with arterial-venous shunt

\begin{tabular}{|c|c|c|c|c|c|c|c|}
\hline \multirow{2}{*}{ Case } & \multirow{2}{*}{ Age } & \multirow{2}{*}{ Sex } & \multirow{2}{*}{ Diagnosis } & \multirow{2}{*}{$\begin{array}{c}\text { Work } \\
\text { performed }\end{array}$} & \multicolumn{2}{|c|}{ Lactic acid } & \multirow{2}{*}{ Remarks } \\
\hline & & & & & Before & After & \\
\hline 17 & $\begin{array}{c}\text { years } \\
32\end{array}$ & $\mathbf{M}$ & $\begin{array}{l}\text { Probably case of interven- } \\
\text { tricular septal defect }\end{array}$ & $\begin{array}{c}\mathrm{kgm} . \mathrm{m} . \\
1175\end{array}$ & $\begin{array}{l}\text { megm. } \\
\text { per cent } \\
22.89\end{array}$ & $\begin{array}{l}\underset{\text { per cent }}{\operatorname{mgm} .} \\
28.34\end{array}$ & Some dyspnea after exercise \\
\hline 18 & 21 & $\mathbf{M}$ & Patent ductus & 2100 & 15.80 & 23.20 & No dyspnea. No fatigue \\
\hline 19 & 31 & $\mathbf{F}$ & Patent ductus & 1275 & 19.65 & 21.73 & $\begin{array}{l}\text { Slight dyspnea after work. } \\
\text { Short of breath on exertion } \\
\text { all life }\end{array}$ \\
\hline 20 & 32 & $\mathbf{F}$ & Patent ductus & 750 & 13.34 & 15.19 & $\begin{array}{l}\text { Only complained of feeling } \\
\text { tired. No dyspnea }\end{array}$ \\
\hline 21 & 28 & $\mathbf{F}$ & Patent ductus & 1250 & 15.44 & 37.87 & $\begin{array}{l}\text { Moderately dyspneic. Breath- } \\
\text { lessness since able to walk }\end{array}$ \\
\hline 22 & 22 & $\mathbf{M}$ & $\begin{array}{l}\text { Interventricular septal de- } \\
\text { fect }\end{array}$ & 1510 & 15.71 & 26.70 & Slight dyspnea \\
\hline 23 & 47 & $\mathbf{M}$ & $\begin{array}{l}\text { Interventricular septal de- } \\
\text { fect }\end{array}$ & 2000 & 21.20 & 31.73 & Slight dyspnea \\
\hline 24 & 12 & $\mathbf{F}$ & $\begin{array}{l}\text { Interventricular septal de- } \\
\text { fect }\end{array}$ & 1095 & 11.88 & 13.00 & No dyspnea \\
\hline 25 & 5 & $\mathbf{F}$ & $\begin{array}{l}\text { Probably interventricular } \\
\text { septal defect }\end{array}$ & 120 & 13.54 & 14.36 & No dyspnea \\
\hline 26 & 6 & $\mathbf{F}$ & $\begin{array}{l}\text { Probably interventricular } \\
\text { septal defect }\end{array}$ & 240 & 14.17 & 14.77 & No dyspnea \\
\hline 27 & 10 & $\mathbf{M}$ & $\begin{array}{l}\text { Interventricular septal de- } \\
\text { fect }\end{array}$ & 1460 & 16.84 & 20.59 & No dyspnea \\
\hline & & & & Average & 16.40 & 24.31 & \\
\hline 28 & 23 & $\mathbf{M}$ & $\begin{array}{l}\text { Interventricular septal de- } \\
\text { fect }\end{array}$ & 1000 & 28.64 & 53.90 & $\begin{array}{l}\text { Marked dyspnea (See Table V, } \\
\text { Group VII) }\end{array}$ \\
\hline
\end{tabular}

Table V. Because of the poor condition of some of these patients it was impossible to submit them to the exercise. Cases 36 and 37 were elderly subjects with acute coronary closure but without apparent signs of congestive failure. Both showed moderately high lactic acid values at rest. It is very likely that the above cases would have developed dyspnea upon exertion. Case 38 had auricular fibrillation in addition to hypertension and coronary arteriosclerosis. His resting lactic acid level was at the upper limit of normal. Following exercise it rose to $30 \mathrm{mgm}$. and moderate dyspnea developed. Case 39 showed a high resting lactic acid value, $37 \mathrm{mgm}$. This was a case of congestive failure resulting from paroxysmal ventricular tachycardia of long duration. This patient was dyspneic and orthopneic.

\section{DISCUSSION}

Effect of cardiac shunts on blood lactic acid

If anoxemia can develop as a result of the shunting of venous blood from the right heart to the left through unaerated channels (veno-arterial) we should expect to find a corresponding increase in the blood lactic acid level following exercise. On the other hand, if the shunt is arterial-venous, then no rise of the blood lactic acid level would be expected. The findings in Table II showing the effect of exercise on the venous blood lactic acid level at rest and following exercise are striking in that they indicate that anoxic anoxemia (6) can occur without cardiac failure. The most obvious explanation of this situation is that adequate amounts of unaerated blood are shunted into the 
TABLE IV

Lactic acid values of venous blood before and after standard exercise in cardiac disorders resulting from rheumatic valvular defects with and without auricular fibrillation

\begin{tabular}{|c|c|c|c|c|c|c|c|}
\hline \multirow{2}{*}{ Case } & \multirow{2}{*}{ Age } & \multirow{2}{*}{ Sex } & \multirow{2}{*}{ Diagnosis } & \multirow{2}{*}{$\begin{array}{c}\text { Work } \\
\text { performed }\end{array}$} & \multicolumn{2}{|c|}{ Lactic acid } & \multirow{2}{*}{ Remarks } \\
\hline & & & & & Before & After & \\
\hline 29 & $\begin{array}{c}\text { years } \\
29\end{array}$ & $\mathbf{M}$ & $\begin{array}{l}\text { Mitral stenosis and aorta in- } \\
\text { sufficiency }\end{array}$ & $\begin{array}{c}k g m . m . \\
1500\end{array}$ & $\begin{array}{l}\underset{\text { per cent }}{\operatorname{mgm} .} \\
19.22\end{array}$ & $\begin{array}{l}\text { mgm. } \\
\text { per cent } \\
28.22\end{array}$ & $\begin{array}{l}\text { Slight dyspnea after } \\
\text { test }\end{array}$ \\
\hline 30 & 16 & $\mathbf{M}$ & $\begin{array}{l}\text { Mitral insufficiency with ste- } \\
\text { nosis }\end{array}$ & 1920 & 11.13 & 13.00 & No dyspnea nor fatigue \\
\hline 31 & 45 & $\mathbf{M}$ & $\begin{array}{l}\text { Mitral stenosis with auricular } \\
\text { fibrillation }\end{array}$ & 718.5 & 21.63 & 23.93 & $\begin{array}{l}\text { Slight cyanosis, fatigue, } \\
\text { and slight dyspnea } \\
\text { after test }\end{array}$ \\
\hline 32 & 43 & $\mathbf{M}$ & $\begin{array}{l}\text { Mitral stenosis with auricular } \\
\text { fibrillation }\end{array}$ & 1575 & 16.01 & 25.17 & $\begin{array}{l}\text { Slightly fatigued and } \\
\text { dyspneic after test }\end{array}$ \\
\hline 33 & 29 & $\mathbf{M}$ & Aortic insufficiency & 840 & 14.87 & 16.00 & $\begin{array}{l}\text { Severe headache. Re- } \\
\text { fused to carry on with } \\
\text { work }\end{array}$ \\
\hline \multirow[t]{2}{*}{34} & 21 & $\mathbf{M}$ & Aortic insufficiency & 1900 & 13.61 & 15.88 & No dyspnea nor fatigue \\
\hline & & & & Average & 16.08 & 20.36 & \\
\hline
\end{tabular}

TABLE V

Lactic acid values of venous blood before and after standard exercise in other cardiac conditions

\begin{tabular}{|c|c|c|c|c|c|c|c|}
\hline \multirow{2}{*}{ Case } & \multirow{2}{*}{ Age } & \multirow{2}{*}{ Sex } & \multirow{2}{*}{ Diagnosis } & \multirow{2}{*}{$\begin{array}{c}\text { Work } \\
\text { performed }\end{array}$} & \multicolumn{2}{|c|}{ Lactic acid } & \multirow{2}{*}{ Remarks } \\
\hline & & & & & Before & After & \\
\hline & years & & & kgm. m. & $\underset{\text { per cent }}{\operatorname{mgm}}$ & $\underset{\text { per cent }}{\operatorname{mgm}}$ & \\
\hline \multicolumn{8}{|c|}{ CORONARY THROMBOSIS, GROUP $\mathrm{v}$} \\
\hline 35 & 60 & $\mathbf{M}$ & $\begin{array}{c}\text { Coronary thrombosis with } \\
\text { diabetes }\end{array}$ & No work & 23.42 & & Occlusion six days old \\
\hline \multirow[t]{2}{*}{36} & 59 & $\mathbf{M}$ & $\begin{array}{l}\text { Coronary thrombosis with } \\
\text { hypertension }\end{array}$ & No work & 19.83 & & $\begin{array}{l}\text { No signs of congestive failure; } \\
\text { angina pectoris for past } \\
\text { seven years }\end{array}$ \\
\hline & & & & Average & 21.67 & & \\
\hline \multicolumn{8}{|c|}{ HYPERTENSION WITH CORONARY ARTERIOSCLEROSIS, GROUP VI } \\
\hline 37 & 50 & $\mathbf{M}$ & $\begin{array}{l}\text { Hypertension with coronary } \\
\text { arteriosclerosis }\end{array}$ & No work & 29.14 & & No signs of congestive failure \\
\hline \multirow[t]{2}{*}{38} & 60 & $\mathbf{F}$ & $\begin{array}{l}\text { As above with auricular fibril- } \\
\text { lation }\end{array}$ & 1.013 & 19.83 & 30.05 & Dyspnea following exercise \\
\hline & & & & Average & 24.40 & 30.05 & \\
\hline \multicolumn{8}{|c|}{ CONGESTIVE FAIIURE, GROUP VII } \\
\hline 39 & 50 & $\mathbf{M}$ & $\begin{array}{l}\text { Ventricular paroxysmal } \\
\text { tachycardia }\end{array}$ & No work & 37.72 & & No cyanosis, pulse 170 \\
\hline \multirow[t]{2}{*}{28} & 23 & $\mathbf{M}$ & Interventricular septal defect & 1000 & 28.64 & 53.90 & Marked dyspnea after exercise \\
\hline & & & & Average & 33.18 & 53.90 & \\
\hline
\end{tabular}


general circulation, thus creating an oxygen deficit (anoxemia). If, following the exercise test the recovery phase be prolonged because of this oxygen shortage, an excessive accumulation of lactic acid will be expected in the venous blood for some time after the termination of the exercise. The amount of unaerated blood shifted will depend on the size of the defect, and the height of blood pressure in the two circuits. As long as the pressure in the right heart or pulmonary artery is maintained higher than on the left side unaerated blood will pass through the defect.

In congenital heart disease, tissue anoxia is apparently not present during rest for the lactic acid values are essentially normal. While the circulation rate may be slowed somewhat if polycythemia is present, enough oxygen seems to be available to remove the lactic acid which is normally formed at rest.

When Table II (cyanotic group) is compared to Table III (acyanotic group) it will be noted that the lactic acid concentration, particularly after exercise, is with only a few exceptions consistently higher in the cyanotic group. The presence of cyanosis, though not directly responsible for higher blood lactic acid levels, indicates a potential state of oxygen deficiency which easily can be precipitated by mild physical exertion. It is a common clinical observation that in congenital heart defects with venous-arterial shunts, cyanosis becomes more intense upon such slight exertion as walking. This observation was made in the cyanotic cases following the exercise test. This is to be attributed to the fact, as pointed out by Haldane (7), that in morbus caeruleus after exercise, the blood returned from the musculature is extremely poor in oxygen. Furthermore, Lundsgaard and Van Slyke (8) point out that as much as one-third of the venous blood entering the right heart chamber must be shunted over directly into the systemic circulation before the cyanotic threshhold is exceeded. In extreme cases of cyanosis as much as two-thirds of the venous stream may be shunted, thus leading to a high degree of oxygenunsaturation. It is reasonable to assume therefore that cyanosis in congenital heart disease indicates the presence and approximate extent of the shunt, though not in quantitative terms.

When polycythemia is present in congenital heart disease it appears to be a compensatory process arising from the stimulation of erythropoietic bone marrow tissue by anoxia. As a consequence the red cell count increases and therefore the capacity of the blood to carry oxygen is increased. In spite of its apparent beneficial effects, its presence indicates, as our studies show, that the liability to tissue anoxia is great even following mild exertion (Table II).

The degree of cyanosis is not necessarily an index of the amount of oxygen lack that will develop following muscular work. Case 16 (Table II) illustrates this point. Two separate sets of determinations were carried out on this individual, the results being in very good agreement. The resting values on both occasions were slightly elevated as compared with the normal group. Following exercise the average rise of lactic acid was about $2 \mathrm{mgm}$. per $100 \mathrm{cc}$. of blood. This patient had continuous cyanosis and following the exercise the cyanosis deepened appreciably, yet the lactic acid rise was only slight. Marked secondary polycythemia was present in this subject, and there was moderate cardiac enlargement. We must conclude from this case that tissue anoxia, at least to any marked degree, may be absent even in the presence of cyanosis and polycythemia. This patient complained of no fatigue after exercise and dyspnea was not noted. $\mathrm{He}$ stated he could easily carry on the work and was the only patient in this group who did not show evidence of fatigue or dyspnea. Obviously there was enough reduced hemoglobin to produce cyanosis, yet there was a sufficient amount of oxygen to prevent a muscle oxygen debt.

\section{Blood lactic acid in acquired heart disease}

When the five uncomplicated cases of mitral stenosis and aortic insufficiency (Table IV) are considered, it will be noted that the lactic acid levels before and after exercise are within normal limits and that the exercise response is the same as in normal subjects. On the other hand, the two cases of mitral stenosis associated with auricular fibrillation showed a moderate rise above the normal lactic acid level. Also, slight to moderate dyspnea was noted after the exercise. It would appear that in cases of valvular defects associated with auricular fibrillation a mild state of anoxia develops following exercise. In this group can also be included Case 38 with hypertension, auricular fibrillation, and evidence of marked en- 
largement of the left ventricle. Dyspnea followed the exercise test and, while the resting level of lactic acid was at the upper limits of normal, the concentration after exercise rose to 30.05 mgm. The lactic acid rise in this case was undoubtedly consequent to left ventricular failure.

Of the two cases of coronary thrombosis studied, Table V, Group V, neither had any signs of congestive failure, still the resting blood lactic acid levels were slightly elevated.

Two cases of congestive failure were studied, Table V, Group VII. Both showed high blood lactic acids levels at rest. Case 28 was given the standard exercise test and the blood lactic acid rose to $53 \mathrm{mgm}$. per $100 \mathrm{cc}$. of blood. This was the highest value recorded in the series, indicating the great tendency to tissue anoxia when the cardiac reserve is impaired.

That the concentration of lactic acid may reach abnormally high concentrations even at rest in cases of circulatory failure was demonstrated by Meakins and Long (9) and confirmed by Jervell (10). They pointed out, furthermore, that the accumulation of lactic acid in the blood was in proportion to the severity of the circulatory failure and was excessively great after exercise. The results in our two cases were in entire accord with the findings of the above investigators.

The increase in the concentration of lactic acid following even mild exercise in cardiac failure must be attributed to a deficient oxygen supply to the tissues. With mild physical exertion the oxygen supply cannot be increased in proportion to the increased oxygen requirement, and a greater accumulation of lactic acid in the blood is found.

\section{Relation of blood lactate values to cardiac insufficiency}

From the studies above it is apparent that the cause of hyperlacticacidemia in acquired heart disease is myocardial insufficiency. It is then necessary to inquire whether the high lactate values obtained in Table II (cyanotic type of congenital heart disease) and Table III (acyanotic type) can be accounted for on the basis of myocardial weakness. In order to obtain data in this direction we submitted the patients with congenital heart disease to radiocardiological and electrocardiographic examination of the heart, the purpose being not only to determine the type of enlargement for diagnostic purposes, but also to determine the degree of enlargement from a viewpoint of cardiac efficiency. The degree of enlargement is a fair index of the severity of the myocardial lesion and of the liability to failure $(11,12,13)$. When Table VI is examined all the post-exercise values are abnormally high except in Case 16. Case 16 showed moderate enlargement of all chambers of the heart, yet the lactate concentration remains about stationary. Certainly from the point of view of enlargement the lactate values after exercise in this instance should be high if myocardial insufficiency were present. On the other hand Cases 11, 12, and 13 showed a very slight degree of enlargement with no evidence of myocardial disease by the electrocardiogram. Yet the lactate values doubled after exercise. From a consideration of these observations it would be inconsistent to attribute the high lactate values to myocardial insufficiency. In Cases 14 and 15 only are we justified in attributing the high lactate value to myocardial insufficiency. Yet in Case 14 gross failure was absent, for the venous pressure was $9 \mathrm{~cm} . \mathrm{H}_{2} \mathrm{O}$.

When Table III (acyanotic group of congenital heart disease) is examined, abnormally high values are found in Cases 17, 18, 21, 22, and 23. Case 17 showed only slight enlargement. Case 18 showed no enlargement. Case 21 revealed a large pulmonary artery with very slight if any enlargement of the right ventricle. Case 22 showed no enlargement of the ventricles except slight enlargement in the region of the conus and Case 23 showed no enlargement. Of course, it is possible that temporary myocardial insufficiency could have manifested itself during exercise.

The above studies demonstrate that two factors may operate either singly or in combination to increase the lactic acid concentration of the blood in congenital heart disease. These are myocardial insufficiency and the presence of either intra or extra cardiac shunts. In the presence of cardiac enlargement, to at least a moderate degree, the cardiac reserve may be impaired and an increase in the blood lactate may be found after exercise. The co-existence of a veno-arterial shunt would heighten the blood lactate value. However, when cardiac enlargement is minimal or absent then the high lactate values may be preponderantly a direct result of the veno-arterial shunt. On the other hand, the elevation of the blood lactate in some cases of the acyanotic group (arteriovenous 
TABLE VI

Significant cardiac findings in the congenital heart groups

\begin{tabular}{|c|c|c|c|c|c|c|c|}
\hline \multirow{2}{*}{ Case } & \multirow{2}{*}{ Diagnosis } & \multicolumn{2}{|c|}{ Lactic acid } & \multirow{2}{*}{ Radiocardiological findings } & \multirow{2}{*}{ Electrocardiogram findings } & \multirow{2}{*}{$\underset{\text { pressure }}{\text { Blood }}$} & \multirow{2}{*}{ Auscultatory findings } \\
\hline & & Before & After & & & & \\
\hline & & $\begin{array}{c}\text { per. } \\
\text { cent }\end{array}$ & $\begin{array}{c}\text { mgm. } \\
\text { per } \\
\text { cent }\end{array}$ & & & $\operatorname{mig}_{\boldsymbol{H} \boldsymbol{g}}$ & \\
\hline
\end{tabular}

CYANOTIC GROUP

\begin{tabular}{|c|c|c|c|c|c|c|c|}
\hline 11 & $\begin{array}{l}\text { Interventric- } \\
\text { ular septal } \\
\text { defect }\end{array}$ & 18.44 & 43.25 & \begin{tabular}{|l}
\multicolumn{3}{|c|}{ Generalized enlargement } \\
slight. \\
Vent. $\dagger$ Pul. Art. $\dagger \quad$ Lt.
\end{tabular} & $\begin{array}{l}\text { Normal rhythm. Low } \\
\text { voltage Lead I. P1 } \\
\text { bifid. P2 P3 promi- } \\
\text { nent. L.A.D. }\end{array}$ & $135 / 80$ & $\begin{array}{l}\text { Systolic murmur all } \\
\text { areas. Loudest over pul- } \\
\text { monic area }\end{array}$ \\
\hline 12 & $\begin{array}{l}\text { Tetralogy of } \\
\text { Fallot }\end{array}$ & 17.98 & 40.94 & $\begin{array}{l}\text { Rt. Vent. } \dagger \text { Lt. Vent. } \dagger \\
\text { Pul. Art. normal. Conus } \dagger\end{array}$ & $\begin{array}{l}\text { Normal rhythm. T1 } \\
\text { T2 prominent and up- } \\
\text { right. T3 inverted. } \\
\text { P tendency to bifid all } \\
\text { leads. R.A.D. }\end{array}$ & $138 / 85$ & $\begin{array}{l}\text { Rough, blowing systolic } \\
\text { murmur over pulmonic } \\
\text { area, but no thrill. 2d } \\
\text { pulmonic absent }\end{array}$ \\
\hline 13 & $\begin{array}{l}\text { Tetralogy of } \\
\text { Fallot }\end{array}$ & 16.00 & 28.44 & $\begin{array}{l}\text { Dextrorotation of aorta. } \\
\text { Pul. Art. not enlarged. } \\
\text { Conus of Rt. Vent. } \dagger \text { and } \\
\text { slight generalized enlarge- } \\
\text { ment }\end{array}$ & $\begin{array}{l}\text { Normal rhythm. } \\
\text { R.A.D. P3 and T3 } \\
\text { flat }\end{array}$ & $135 / 82$ & $\begin{array}{l}\text { Harsh, rough systolic } \\
\text { murmur and systolic } \\
\text { thrill over pulmonary } \\
\text { area. 2d pulmonic sound } \\
\text { absent }\end{array}$ \\
\hline 14 & $\begin{array}{l}\text { Patent } \\
\text { ductus } \\
\text { arteriosus }\end{array}$ & 13.20 & 28.68 & $\begin{array}{l}\text { Pul. Art. f† Conus. } \dagger \text { Rt. } \\
\text { Vent. } \dagger \text { Lt. Vent. } \dagger \text { Ve- } \\
\text { nous pressure } 9 \mathrm{~cm} . \mathrm{H}_{2} \mathrm{O}\end{array}$ & $\begin{array}{l}\text { Normal rhythm. } \\
\text { L.A.D. P.R. interval } \\
=0.26 \text { sec. }\end{array}$ & $128 / 65$ & $\begin{array}{l}\text { Machinery-like murmur } \\
\text { heard maximum over } \\
\text { pulmonic area. 2d pul- } \\
\text { monic sound present }\end{array}$ \\
\hline 15 & $\begin{array}{l}\text { Interventric- } \\
\text { ular septal } \\
\text { defect asso- } \\
\text { ciated with } \\
\text { patent } \\
\text { ductus } \\
\text { arteriosus }\end{array}$ & 20.88 & 47.10 & $\begin{array}{l}\text { Pul. Art. } t \dagger \text { Rt. Vent. } \dagger \dagger \\
\text { Conus. } t \dagger \text { Lt. Vent. } \dagger\end{array}$ & $\begin{array}{l}\text { Notching of } P \text { waves } \\
\text { in Leads I and II. } \\
\text { Otherwise normal. } \\
\text { Normal rhythm }\end{array}$ & $125 / 85$ & $\begin{array}{l}\text { Systolic murmur heard } \\
\text { over 3d interspace just } \\
\text { to left of sternum }\end{array}$ \\
\hline 16 & $\begin{array}{l}\text { Patent duc- } \\
\text { tus arteriosus } \\
\text { associated } \\
\text { with inter- } \\
\text { ventricular } \\
\text { septal defect }\end{array}$ & 20.78 & 22.01 & 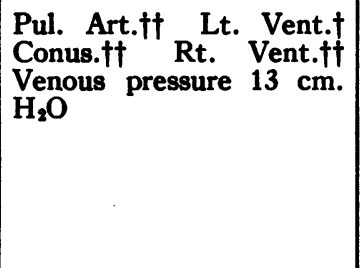 & $\begin{array}{l}\text { R.A.D. High P2 T2. } \\
\text { Increased amplitude of } \\
\text { Q.R.S. complexes. } \\
\text { Normal rhythm }\end{array}$ & $130 / 82$ & $\begin{array}{l}\text { 2d pulmonic sound mark- } \\
\text { edly accentuated. Sys- } \\
\text { tolic murmur heard best } \\
\text { over 3d interspace to left } \\
\text { of sternum preceded by } \\
\text { snapping 1st sound and } \\
\text { followed by snapping } 2 \mathrm{~d} \\
\text { sound followed by soft } \\
\text { blowing diastolic murmur }\end{array}$ \\
\hline
\end{tabular}

ACYANOTIC GROUP

\begin{tabular}{|c|c|c|c|c|c|c|c|}
\hline 17 & $\begin{array}{l}\text { Probable case } \\
\text { of interven- } \\
\text { tricular } \\
\text { septal defect }\end{array}$ & 22.89 & 28.34 & $\begin{array}{l}\text { Pul. Art. sl. enlargement. } \\
\text { Rt. Vent. } \dagger \text { Conus } \dagger\end{array}$ & $\begin{array}{l}\text { Normal rhythm. T2 } \\
\text { T3. Inverted. } \\
\text { A.D. }\end{array}$ & $100 / 60$ & $\begin{array}{l}\text { Basal systolic thrill pul- } \\
\text { monary region. Systolic } \\
\text { murmur all areas, maxi- } \\
\text { mum over base }\end{array}$ \\
\hline 18 & $\begin{array}{l}\text { Patent } \\
\text { ductus } \\
\text { Botalli }\end{array}$ & 15.00 & 23.00 & $\begin{array}{l}\text { No generalized enlarge- } \\
\text { ment. Pul. Art. } \dagger \text { and } \\
\text { pulsating }\end{array}$ & $\begin{array}{l}\text { Rt. A.D. Normal } \\
\text { rhythm }\end{array}$ & $145 / 95$ & $\begin{array}{l}\text { Short blowing systolic } \\
\text { murmur over apex. Sys- } \\
\text { tolic thrill over pulmon- } \\
\text { ary area with systolic } \\
\text { murmur. 2d pulmonic } \\
\text { sound present }\end{array}$ \\
\hline
\end{tabular}


TABLE vI-Continued

\begin{tabular}{|c|c|c|c|c|c|c|c|}
\hline \multirow{2}{*}{ Case } & \multirow{2}{*}{ Diagnosis } & \multicolumn{2}{|c|}{ Lactic acid } & \multirow{2}{*}{ Radiocardiological findings } & \multirow{2}{*}{ Electrocardiogram findings } & \multirow{2}{*}{$\begin{array}{c}\text { Blood } \\
\text { pressure }\end{array}$} & \multirow{2}{*}{ Auscultatory findings } \\
\hline & & Before & After & & & & \\
\hline & & $\begin{array}{c}\text { mgm. } \\
\text { per } \\
\text { cent }\end{array}$ & $\begin{array}{c}\text { pgm. } \\
\text { per } \\
\text { cent }\end{array}$ & & & $\operatorname{mm}_{\boldsymbol{H}}$ & \\
\hline
\end{tabular}

ACYANOTIC GROUP (Continued)

\begin{tabular}{|c|c|c|c|c|c|c|c|}
\hline 19 & $\begin{array}{l}\text { Patent } \\
\text { ductus } \\
\text { arteriosus }\end{array}$ & 19.00 & 21.00 & $\begin{array}{l}\text { Pul. Art. } \dagger \text { with pulsation. } \\
\text { R.V. } \dagger \text { Conus. } \dagger \text { Pul. } \\
\text { branches } \dagger\end{array}$ & $\begin{array}{l}\text { R.A.D. Normal } \\
\text { rhythm }\end{array}$ & $120 / 90$ & $\begin{array}{l}\text { Systolic thrill and mur- } \\
\text { mur over 1st and } 2 d \text { left } \\
\text { interspaces }\end{array}$ \\
\hline 20 & $\begin{array}{l}\text { Patent } \\
\text { ductus } \\
\text { arteriosus }\end{array}$ & 13.00 & 15.00 & $\begin{array}{l}\text { Pul. Art. ft Other changes } \\
\text { slight }\end{array}$ & $\begin{array}{l}\text { R.A.D. Normal } \\
\text { rhythm }\end{array}$ & $130 / 80$ & $\begin{array}{l}\text { Machinery-like murmur } \\
\text { heard over pulmonicarea. } \\
\text { 2d pulmonic sound heard }\end{array}$ \\
\hline 21 & $\begin{array}{l}\text { Patent } \\
\text { ductus } \\
\text { arteriosus }\end{array}$ & 15.44 & 37.87 & $\begin{array}{l}\text { Pul. Art. } t \text { with marked } \\
\text { pulsation of pulmonary } \\
\text { vessels. No aortic win- } \\
\text { dow. Conus. } t \text { Sl. en- } \\
\text { largement of rt. vent. only }\end{array}$ & Bifid. P2 P3 & $110 / 65$ & $\begin{array}{l}\text { Systolic and diastolic } \\
\text { murmur over pulmonary } \\
\text { artery and thrill }\end{array}$ \\
\hline 22 & $\begin{array}{l}\text { Interventric- } \\
\text { ular septal } \\
\text { defect }\end{array}$ & 15.00 & 26.00 & $\begin{array}{l}\text { Slight enlargement in co- } \\
\text { nus region }\end{array}$ & Normal & $110 / 70$ & $\begin{array}{l}\text { Loud rough systolic mur- } \\
\text { mur heard maximum } \\
\text { along sternal border with } \\
\text { systolic thrill at level of } \\
\text { 3d interspace }\end{array}$ \\
\hline 23 & $\begin{array}{l}\text { Interventric- } \\
\text { ular septal } \\
\text { defect }\end{array}$ & 21.00 & 31.00 & No definite enlargement & Normal & $135 / 80$ & $\begin{array}{l}\text { Loud rough systolic heard } \\
\text { best over lower sternum } \\
\text { with systolic thrill }\end{array}$ \\
\hline 24 & $\begin{array}{l}\text { Interventric- } \\
\text { ular septal } \\
\text { defect }\end{array}$ & 11.00 & 13.00 & No definite enlargement & Normal & $110 / 60$ & $\begin{array}{l}\text { Loud rough systolic mur- } \\
\text { mur heard over entire } \\
\text { sternum but heard maxi- } \\
\text { mum along left sternal } \\
\text { louder at level of 4th } \\
\text { interspace accompanied } \\
\text { by systolic thrill }\end{array}$ \\
\hline 25 & $\begin{array}{l}\text { Probable } \\
\text { case of inter- } \\
\text { ventricular } \\
\text { septal } \\
\text { defect }\end{array}$ & 13.00 & 14.00 & No enlargement & Normal & $100 / 60$ & $\begin{array}{l}\text { Loud rough systolic mur- } \\
\text { mur heard maximum } \\
\text { along left sternal border } \\
\text { at level of } 3 \mathrm{~d} \text { interspace } \\
\text { accompanied by systolic } \\
\text { thrill }\end{array}$ \\
\hline 26 & $\begin{array}{l}\text { Interventric- } \\
\text { ular septal } \\
\text { defect }\end{array}$ & 14.00 & 14.77 & $\begin{array}{l}\text { Rt. Vent. } t \text { Conus.tt } \\
\text { Lt. Vent. } t\end{array}$ & R.A.D. & $98 / 58$ & $\begin{array}{l}\text { Thrill and loud systolic } \\
\text { murmur elicited over } \\
\text { level of } 3 \mathrm{~d} \text { interspace just } \\
\text { to left of sternum }\end{array}$ \\
\hline 27 & $\begin{array}{l}\text { Interventric- } \\
\text { ular septal } \\
\text { defect }\end{array}$ & 16.00 & 20.00 & $\begin{array}{l}\text { Rt. Vent. } \dagger \text { Conus. } \dagger \text { Pul. } \\
\text { Art. not enlarged }\end{array}$ & Normal & $105 / 60$ & $\begin{array}{l}\text { Systolic murmur loud } \\
\text { rumbling, heard best over } \\
\text { 3d interspace just to left } \\
\text { of sternal borders. Level } \\
\text { of 3d interspace }\end{array}$ \\
\hline 28 & $\begin{array}{l}\text { Interventric- } \\
\text { ular septal } \\
\text { defect. } \\
\text { Congestive } \\
\text { failure }\end{array}$ & 28.64 & 53.90 & 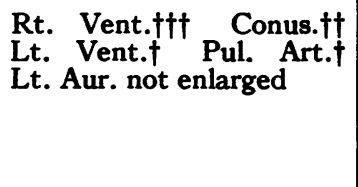 & R.A.D. & $130 / 78$ & $\begin{array}{l}\text { Systolic murmur loud } \\
\text { and harsh heard best } \\
\text { along left sternal border } \\
\text { at level of } 2 \mathrm{~d} \text { interspace. } \\
\text { Diastolic murmur ques- } \\
\text { tionable }\end{array}$ \\
\hline
\end{tabular}

t† $=$ Moderate enlargement.

$t=$ Slight enlargement

L.A.D. = Left axis deviation.

Rt. Vent. $=$ Right ventricle.
R.A.D. = Right axis deviation.

tt† = Considerable enlargement.

Lt. Vent. = Left ventricle.

Pul. Art. = Pulmonary artery. 
shunts) requires further explanation. The high values cannot be explained on the basis of myocardial insufficiency because it would be extremely difficult to comprehend how a heart normal in size and not showing any evidence of myocardial disease could become temporarily incompetent during mild exercise. It is our impression that the high lactate values obtained are probably due to the shunting of blood from the left to the right side of the heart through large defects and that therefore the output of blood through the aorta into the peripheral circulation does not increase in proportion to the oxygen demand of the muscles in exercise.

From the foregoing survey it is apparent that the hyperlacticacidemia which develops after exertion is constantly associated with the presence of dyspnea, regardless of the cause of anoxemia. When dyspnea is present one can predict the occurrence of abnormally increased amounts of lactic acid in the tissues and blood during exercise. Valentin (14) previously adduced evidence to show that blood lactic acid is high in all conditions involving dyspnea. The observations made in this study indicate that dyspnea invariably accompanies the anoxemic state.

\section{CONCLUSIONS}

1. An increased concentration of lactic acid in the venous blood is evidence of an inadequate supply of oxygen to the tissues.

2. There is only a slight increase of lactic acid in the blood following mild exercise in normal individuals, an average increase of about $2 \mathrm{mgm}$. per $100 \mathrm{cc}$. of blood above the resting value. The normal upper limit of concentration of venous blood lactic acid following our exercise test did not exceed $21 \mathrm{mgm}$. per $100 \mathrm{cc}$. of blood.

3. The blood lactic acid studies show that tissue anoxia is not present at rest in patients with congenital heart disease, either in the presence or absence of cyanosis.

4. Following mild exercise there is a definitely abnormal rise of blood lactic acid in the cyanotic group of congenital heart disease, indicating a greater liability to the development of tissue oxygen deficit after even slight physical exertion.

5. The presence of cyanosis and polycythemia in congenital heart disease does not necessarily indicate that oxygen deficit will develop following mild exertion for no significant rise of lactic acid level occurred in a case of morbus caeruleus.

6. Following mild exertion, a definitely abnormal rise may occur in some acyanotic cases of congenital heart disease, but the rise is not as great on the average as in the cyanotic group.

7. When dyspnea follows mild exercise the presence of tissue oxygen want may be assumed to be present regardless of what specific cardiac defect is ultimately responsible.

\section{BIBLIOGRAPHY}

1. (a) Hill, A. V., The mechanism of muscular contraction. Physiol. Rev., 1922, 2, 310.

(b) Hill, A. V., and Long, C. N. H., Muscular exercise, lactic acid and the supply and utilization of oxygen. Ergebn. d. Physiol., 1925, 24, 43.

(c) Hill, A. V., Long, C. N. H., and Lupton, H., Muscular exercise, lactic acid and the supply and utilization of oxygen. Part I. Introduction. Proc. Roy. Soc., s.B., 1924, 96, 438.

2. Meyerhoff, O., Chemical Dynamics of Life Phenomena. Lippincott, Philadelphia and London, 1924.

3. Hallock, P., Blood lactic acid after exercise with particular reference to polycythemia rubra vera. Proc. Soc. Exper. Biol. and Med., 1938, 38, 587.

4. Freidemann, T. E., Cotonio, M., and Shaffer, P. A., The determination of lactic acid. J. Biol. Chem., 1927, 73, 335.

5. Peters, J. P., Van Slyke, D. D., Quantitative Clinical Chemistry. Vol. I. Interpretations. Chapter X. Williams and Wilkins Company, Baltimore, 1931.

6. Barcroft, J., Anoxemia. Lancet, 1920, 2, 485.

7. Haldane, J. S., Respiration. Yale University Press, New Haven, 1922.

8. Lundsgaard, C. and Van Slyke, D. D., Cyanosis. Medicine Monographs. Williams and Wilkins Co., Baltimore, 1923.

9. Meakins, J., and Long, C. N. H., Oxygen consumption, oxygen debt and lactic acid in circulatory failure. J. Clin. Invest., 1927, 4, 273.

10. Jervell, Otto, Investigations of the concentration of lactic acid in blood and urine. Acta med. Scandinav., 1928, Supp. 24, Chapter III, pp. 23 to 26.

11. Parkinson, J., Enlargement of the heart. Lumleian Lectures. Lancet, 1936, 1, 1337 and 1391.

12. Grant, R. T., After histories for ten years of 1000 men suffering from heart failure. Heart, 1933, 16, 275.

13. Hallock, P., Enlargement of the heart. Its recognition by the radiologic method. Minnesota Med., 1938, 21, 303.

14. Valentin, F., Über den Milchsäuregehalt des Blutes. München. med. Wchnschr., 1925, 72, 86. 